\title{
準備委員会企画シンポジウム
}

\section{I 「子ども理解のための発達研究と臨床一心の基礎研究一」}

企 画 者 齋藤久美子 (京 都 大 学)

企画・司会者 岡本夏木 (京都女子大学)

話題提供者 田島 信元 (東京外国語大学)

内田 伸子（お茶の水女子大学）

片岡 基明 （近江八幡市立心身

障害児通園センター)

齋藤久美子（京 都 大 学）

指定討論者 守屋 慶子 (立 命 館 大 学)

山口 俊郎 (兵 庫 教 育大学)

\section{企画・司会者}

岡本 夏木

子どもについての発達的研究と臨床的研究は, 相互に 相手の領域を意識しながらも，かなり独立して，時には 対立とも思われるような形をとって進められて来た。し かし真の子ども理解に迫るには，両領域がより近づき合 うことが求められて来ている。本シンポジウムでは，主 として乳幼児に焦点をあてながら，両領域からの一歩接 近のための提言を求めることにした。

田島氏は，母子間の相互交涉過程を意味的相互作用と して解釈してゆく方法を提示し，内田氏は，子どもの物 語表現を意味的世界を作り出すいとなみとしてとらえ， そこでのおとなとのコミュニケーションを通して，子ど もから物語を引き出してゆく側面を強調した。両氏とも に，その際に働く間主観性を重視しながら，そこから従 来の発達研究的内容をより臨床的方向に近づけてとらえ 直してゆくことを示唆する提言であった。

片岡氏は障害をもつ乳幼児に毎日接する経験の中から， その臨床的内実を母一子療育者の三者間関係の中で, それらが来所時からどう変化し，その中で療育者がどの ような仮説をたてて活動してゆくか，またそこで一般者 としての態度と研究者としての態度の間を療育がどう往 き来するかが問題になることを指摘した。

齋藤氏は，対人的「関係」形成の歩みと，自律的な「個」 の機構形成の間の中で，幼児が経験するさまざまのジレ ンマ, 特に治療的対象となる子どもの場合をとり上げな がら, 子どもの成長の舞台裏の理解の必要を述べた。

指定討論者の守屋氏と山口氏からは, 主として方法論 的立場から, 発表者の試みが, どの程度子どもの内面性 と，また因果性や一般性をとらえてゅくことが可能かに
ついて質問がなされた。フロアーから十分な意見を聞く 時間を持てなかったが，来聴も早く，初期の目的は一応 果たしたと思われる。

\section{発達は社会的・意味的相互作用を通して達成される}

一「相互主観的」相互作用の発達過程の分析一

田島 信元

子どもの心の働きとその変容過程についての近年の発 達心理学的研究は, 本シンポジウムの共通テーマである 「表現する心」,「かかわり合う心」に焦点化され, かつ, 臨床的理解を目指しつつあるといえよう。

そうした傾向の一つの現れは, 発達・学習の概念の変 化にみてとれる。これは発達と学習の区別を廃し, マイ クロな発達過程としての学習過程を詳細に分析していく こと, そして学習を知識・情報の内化過程として捉える のではなく, 実践共同体への参加を通しての実践的行為 として捉えるところに特徴がある。そのために, 実践活 動を行うシステムや客観的形態，および，それらに対す る行為者の主観的, 相互主観的な理解のあり方を分析の 対象とするのである。こうした状況的，相互主観的理解 は発達への臨床的アプローチのひとつといえるだろう。

以上のような発想のもとに, 生後 3 か月から 65 か月に わたる縋断的な 8 時点での自由遊びの場面における母子 相互作用過程のケース・データを分析し，母子が共同世 界の認識を形成していくとき，母ないし子どもはどのよ うな点に注目し，どういう点をきっかけにして，お互い に認識を変容させていくのか, ということを吟味してみ た。分析方法としては，母子のやりとりにおける言語的， 行動的表出の機能的意味を析出するプロトコル分析と, 複数の観察者に母子関係のどのような点に注目するかと いうことと，その手がかりとなる具体的な行動を報告さ せ，母子それぞれの行動の機能的意味づけのあり方を明 らかにするナラティブ分析を併用した。結果は, プロト コル分析が母子それぞれの自己ないし相手の行動に対す る意味づけのあり方は, 相手の反応に依存して変化し, 最終的に共通の意味世界を共有していくという相互主観 的相互作用の状況を明らかにするとともに，ナラティブ 分析では, 注目されやすい行動は次期のメインの行動と なっていることを明らかにした。つまり，母子間での顕 著性の高い行動は，その方向で相互に働きかけあい，固 
められやすいということを示唆するもので, プロトコル 分析の結果と同様, 相互主観的相互作用の状況を示すも のと捉えられた。このように発達は社会的・意味的相互 作用を通して達成されるということを強く示唆するとと もに, 発達研究においても, 状況に埋め込まれたことば (分析単位)を採用した臨床的理解の必要性が強調された。

\section{子どもの語りを支える“間主観的場” の役割}

内田 伸子

遊びに見られる子どもの表現は，子どもを取り巻くも のやことについての認識をつくりあげる手段,「世界づく り」の手段である。これを何が支えているかについて子 どもの語りの発達についての知見から探ってみたい。

I ． 物語の語り手としての子ども；

多くの子どもは, 幼児期を通じてお話しを語り聞かさ れるだけでなく, 自分も語り手として発達していく。幼 児期の終わりごろ, 5 歳後半以降になると,身近に起こっ た出来事の報告だけでなく,「物語」と呼べるような語り をするようになる。言語が発生する以前から, 物語の基 底をなす意味が発生し，からだで，さらにことばでそれ を表現しようとする。やがて, 文法の規則, とくに因果 や時間関係を表現しようとする規則の運用により, 過去 一現在一未来の時間軸にそって素材を組合わせて文脈を 作り出す。加齢とともに試練を克服し, 難題や欠如状況 を解決して標準状態へ復元するという演出を好んでする ようになる。これは, 標準状態がどういうものかを理解 し，逸脱を標準へと復元する見通しをもち始めたことを 意味している。登場人物の行動の目標や動機が理解され たとき，何か欠けているということが認識できるとき， 統括性ある物語を展開できるようになり, 主人公の状況 が完全に理解できる。これは, 欲求や動機, 欠如の状況 が人を行動に駆り立て, どんなことが起こるかが予測で きるようになったのであろう。さらに物語文法など語り の構造が洗練していくにつれ, 自分の経験を取り出し, 自在に組合わせて文脈を作り出すようになる。ある経験 を別の文脈に組み込むことにより, その経験の別の局面 が見えたり, 対象化されやすくなるであろう。物語, 特 に架空の出来事を組み込んだファンタジーは, 現実とか け離れた虚構世界へと子どもを誘うものではなく, 現実 には実現していないことを想像の世界で実現する術を模 索する建設的な認識の営みであり, 子どもの経験を一般 化し, 抽象化するための「シミュレーション」なのでは ないかと考えられる。

II . 物語を支える認知機能の発達 ;

物語の産出において, 現象上で生ずる質的な発達的変 化の時期は 2 つある。第 1 に, 3 歳半〜 4 歳にかけて全
く事象が関係づけられない段階から, 大人の誘導や援助 があれば，事象をことばの上で関係づけ，統合すること のできる段階へ変化する。第 2 に, ことばで大人の援助 なしに一貫した物語を語れるようになり，回想や夢の シーンを構成できるようになっていく。この変化が起こ るのはほほ 5 歳後半以後である。この時期には, 主人公 の行動目標や筋の展開を構想するプラン機能, 話の進行 がプラン通り進行しているかを監視し, 評価するモニ ター機能が働き始める。また，時間概念も成立してくる。 5 歳頃から顕著に子どもの語る物語構造が整い, 物語る 営みだけではなく, 他の遊びにおいてもの中でもプラン をたてたり，未来を想像したり，自分の行為を内省した りするなどの内面化の傾向を背後で支えているのは, こ れらの認知機能や情報処理の拡大, 語彙や文法の発達, 物語文法の成立なのであろう。

III. 間主観的関係としての語りの場 ;

実験場面は実験者としての大人と被験者としての子ど もの間の「コミュニケーションの場」である。大人が子 どものことばを受け止めることができるからだでゆった りと向かうとき, 気力を充実させ全身を子どもに向かっ て開くときに，子どもは最も雄弁な語り手となる。自己 を表現する心は, 他者と関わる心と表裏一対をなし, 間 主観的関係において十全に発揮できるようになるのであ る。

\section{「個」と「関係」の両機能をめぐる子ども理解}

齋藤久美子

子どもは発達早期から, 養育者と相互作用的に「関係」 形成への歩みを進める。と同時に，認知、現実支配(探索・ 操作), 感情体験, 自己調節, 同一性などを備えた自律的 な「個」の機構の形成へと向かって行く。それらは, 生 物・心理・社会的と総称される漸成過程の中で, さまざ まな自己表出・表現を伴いながら展開する。

I . 両機能の結び合い, そのバリエーション

本来, 両者は互いに発達促進的に作用し合う筈のもの であり,一般健常児の中に, その典型的な相乗効果が見 られたりする。全般的な発達の流れとしては，母子関係 に見られる通り，早期ほど「個」は「関係」の中に絶対 依存的に包み込まれており,やがて自と他が境界を成し て分立して行くことと「関係」が相互性の次元へ移行す ることとが相携え合って生じて行く。そうなる程に,「関 係」が「個」にとって持つ意味, 両者の循環の質も変容 していく。

臨床児を見ると，片方が犠牲になるなど両者間のアン バランス，あるいはそれぞれの歪みや停滞が見られ，そ の修復や再発達が, 大きな臨床課題となって行く。スト 
レスフルな「関係」の下で, 過剩適応や偽りの適応に向 けて歪んだ方向に「個」が形成されて行く例，また他方， 認知や行動レパートリーを一定度備えた「個」の形成が， 欲求阻止の要素を欠いた「関係」だけに依拠して, 進ん でいく例などが，多様に見られる。後者は，「関係」が十 分開かれず質的にも限られたものに止まっているという 犠牲の下での,「個」の形成だが,この場合結果的には「個」 の機能そのものも偏りや狭まりを免れ得ない。少なくと も感情の発達的分化が対人的「関係」を十分通ることな しに生じて行くことがないことからも, それは明らかで ある。

$2 つ$ 機能が生産的に結び合っているとは限らない場 合を含めて，2つの間柄のバリエーションはむしろ人生 全体を通しての問題として生じて行くが, 幼児期に顕著 な 1 つの問題が次のように存在する。

\section{II. 両機能間の幼児期的ジレンマ}

臨床児だけでない幼児一般にわたる, 発達上の節目的 課題として注目されるのは, 2 才前後の約 1 年余りの心 の状況である。M．マーラーが分離・個体化の見解から とらえた「rapproachment crisis (再接近期危機)」はそれ を端的に示している。それはよく見れば身近に私たちが その姿をとらえることができるものでもあり，次のよう な観察と理解である。

最も近しかった養育者（母親）との細やかな間主観的体 験の共有という，共感的な「関係」を手元から離さない ままでいるか, あるいはそこを離れて外界の事物探索を 心ゆくまで進める方向に「個」の機能を解き放つかとい うジレンマが幼児にうかがえる。

無二の依存対象と密着した位置に居り，そこで末熟な 「個」の能力が全面的に肩代わりされることによって体 験されていた全能性の感覚は, 興にまかせて外界へと愛 着基地を離れるとき,どうなるか。

自力による探索活動の中で, 幼児は, 能力面での試練 や限界体験と同時に，母親からの情緒的応答や調律と いった支充られ関係」がポータブルでないことを体 験しなければならない。外界の事物を指向する内発性は, 「個」の機能を培う好機でありながら同時に, 全能性自己 の拠点からの分離であり, 親密な関係からの遠ざかりで ある。それは「関係」における疎外体験へとつながりか ねない。

この時点の幼児は, 愛着基地への唐突な舞い戻りと, 一方外界への飛び出しとの間を, 行動面でめまぐるしく 繰り広げ, 妥協策さながらに母親の膝にモノを一杯積み 上げに戻ったりするが，それらは心の過程そのものとし て理解される。「個」と「関係」両機能の間での 1 つの引 き剝かれであり，両価的なもがきの体験である。それは
分離不安と自他融合不安の両面を伴う。一般健常児にお いても，この種のもがきがいかに助けを求めるスべのな い，本質的に孤独な体験であるかが観察される。そこに は，自分がどちらをどのように求めているのか，自分の 欲求そのものがわからなくなる混乱がうかがえる。それ は形にしたり，自分で語り出し訴えたりすることから遠 く隔たった体験であり，症状や行動化によって表出され る他ない性質のものとして注目される。臨床場面で, 治 療者を定位置に離して別のことをさせておかないと遊べ ない子ども，また常に治療者から注意を離さず，自分自 身は何もこれと言って遊べない子どもなどに出会う私た ちである。

\section{「子どもの理解のための発達研究と臨床一心の基礎研究一」} 守屋 慶子

間主観性の概念について：各々の経験する主観的相互 作用を捉えるのは難しい。研究者の側の主観ですべてが 計画され, 解釈, 処理されてきた従来の研究を, 被験者 の視点で捉え直すという方向は評価できるが，それがて きると考えるのは幻想に近いのではないか。ナラティ ブ・メソッドやプロトコル分析がこの点に関して万能だ とは考えられない。

「実験的に測る」ことについて：これについて否定的評 価が述べられたが「実験的に測る」というのも一つの文 脈，つまり共同的意味的世界の無い文脈での観察であり， 心理学が因果的説明を担わなければならないとしたら必 要ではないか。

「日常の語りの意味」について：実験者に聞かせる子ど もの語りは, 子どもの視点からは実験者の要請を受け入 れなければならないという課題に応じた相互作用だが, 日常の子どもの語りは彼らの主観ではどのような意味を もつ相互交渉なのだろうか。

「客観的捉え方」について：片岡氏が「客観的捉え方」 とみなす捉え方ははたして客観的なのか。客観的と呼ば れてきた発達研究には，研究者の主観的分析と考えたほ うがよいものが多い。ただし，研究者の主観的分析は悪 いわけではなく，「客観的捉え方」は，むしろこのような 多くの主観的分析のつき合わせによりはじめて取り出せ るものと考えられるがどうなのか。

「子どもの心」について：子どもの心は療育者や実験者 との関わり方の上手，下手に応じてその表現が十分で あったり不十分であったりする，そういう静的な実体的 なものとは考えられない。それは関わり方の如何に関わ らず，活動しつつある存在としてそこに十全に現れるも のではないか。このように考えるからこそ，多様な主観 による子どもとのつき合いが必要であり，また，だから 
こそ研究における間主観性が重視されねばならないので はないか。

因果関係の発見について：心理学には因果的説明が期 待されていると考えるが, 従来の横断的研究, 縦断的研 究, あるいは実証的研究, 臨床的研究などは, もともと 単独で因果関係を発見できる仕組みにはなっていない。 もし臨床研究が治療と同時に因果的説明を目指し, そし て発達研究が現実の場面, 社会的相互作用の文脈で実験 を試みることができれば因果関係の発見は可能ではない か。関わる問題が常に日常文脈的であり, かつ縦断的性 格の臨床研究では, 行動や心的過程の間の関係が発見し 易いが，その関係が因果的関係か否かの確認はできない。 その確定の役割を担えるのは横断的, 実験的研究であろ う。こうした両者の協同研究は因果的説明を可能とする 有効な方法の 1 つと考えられるが, 実現の可能性はある のだろうか。

\section{話題提供者}

\section{「早期療育での子ども理解」}

片岡 基明

就学前の障害をもつ乳幼児の療育現場で, どのような 「子ども理解」が行われているかについて考察・報告し， 話題提供としたい。

療育者としては，大まかに分けて 2 つの方向での努力 がなされている。

ひとつは, 子どもの姿をできる限り「客観的に」とら えようとする方向。このために, 療育者は各種の検查な どを用いて子どもの状況を探ろうとする。検査を用いな いとしても，子どもにある種の意図的な働きかけをし， その反応を見ることで子どもの発達レベルや対人関係の 持ち方などを判断するのである。たとえば, 出会ったと き声をかけたらどうか, プレイルームをどのように探索 するか, 遊んでいるときに横にいればどうか, 子どもの することを真似てみるとどうするか, 別のおもちゃを出 してみたらどうするか, 等々たくさんの情報が得られる。 これらの観察から, 子どもについての「仮説」を作り, 以後の療育を考える訳である。

通園療育の積み重ねは, 一方では子どもと療育者との 間で起きるエピソードの積み重ねでもある。そのエピ ソードにおいて, いわば「なまに」感じられる子どもの 姿がある。これを感じ取っていく努力がもうひとつの方 向である。それは時期によって変わってくるものであり, 子どものしていることへの了解性が高まるときもあれば， 逆に不可解に感じられることが出てくることもある。そ ういったことが先の「仮説」を修正していき，またそれ 以上に「仮説」では述べられない子どもの姿を語ること
になる。

この 2 つのとらえというあり方は, 今回のシンポジウ ムのテーマに触れるところが大きいように思われるが, 両者の総合の難しさは日々感じられるところである。

さて,こういった両面での療育者のとらえは, 母親(家 族)に語られ，母親が持つ子どものとらえと重ねられてい く。そのことが，母親のとらえを多角的なものにし，子 どもとの関係性を豊かなものにしていく。療育現場でま ず目指されるべきはこのような過程であろう。「正しい」 子ども理解があるわけではなく, むしろ変容していくそ の時々での母親のとらえこそが, 早期療育における「子 ども理解」の実質であるとしてよいのではないだろうか。

\section{指定討論者}

\section{山口 俊郎}

私の専門は児童精神医学であるが，これまでつねに発 達研究に大きな期待を寄せてきた。発達研究は, 発達の 標準的なモデルや基準を提供し，それらを規定する種々 の要因を明らかにしてくれると考えたからである。しか し, 膨大な発達研究の多くは, そのままでは臨床実践や 研究に適用できないことの連続であった。その原因とし ては，それぞれの領域で扱う対象者とその接近方法も非 常に異なっているからであると考えられる。それらの相 違を明確に意識化しなければ, 発達研究と臨床とを結び つける有効な方法は生み出されないと考えられる。健常 児を対象とする発達研究では, 子どもの, ある領域での 能力や特性の標準的なあり方はどのようなものであるか が探求される。つまり, ある年齢段階での代表例は,「〜が できる」という，いわば健常児の典型例が選定される。 例えば，内田氏の「子どもの語りの成立」では，物語を 支える認知機能の発達基準を明らかにするためには，多 くの同年齢児の中から, WPSSI の文章問題を暦年齢相 当で通過している子どもたちだけを対象としている。一 方, 臨床でも, 病理例の典型例ないしは中核群を重要と しているが，そういった例は臨床で扱う症例のごく一部 にしか過ぎなく, その背後には数多くの周辺群があり, さらには周辺群にもなりえない子どもたちがいる。そし て, 臨床でも, 典型例についての症例報告はあっても, その数倍はあると思われる周辺群についての症例報告は 非常に少ない。このように考えると，健常児の典型例と 病理例での中核群と周辺群は, ある年齢の子どもの全体 の中での一部でしかなく, その中間には, 発達研究でも 臨床でも取り扱われない「あいまいな」中間群が存在す る。それらの中間群を, どう取り扱うかが, 発達研究と 臨床をつなぐ一つの問題となってくるのではないかと思 われる。内田氏の「物語づくり」の研究では, ある基準 
を満たして対象となった子どものうちでも，物語の登場 人物の行動の目標や動機が理解できたのは, 3 分の 2 し かなく，それからはずれる子どもは，厳密には分析の対 象とはされていないようである。しかし，臨床の場にい る者にとっては,この除外された子どもこそが重要であ るように思われる。それはどういう子どもか, そういっ た子どもはどのような反応を示したのか。そういった群 での知見が臨床では役に立つのではないか, あるいはこ れらの例でこそ, 間主観性の吟味が意味を帯びてくるの
ではないだろうか。また, 発達研究では, 研究の目的が 先に明らかにされ，観察方法が厳密に規定され，それら に基づいて対象が選択されるが, 臨床では, 片岡氏や齊 藤氏が示すように, 先に雑多な症例があって, それらの 例での長期間の観察から, ある傾向や変化の方向が明ら かにされていくという，対象児へのアプローチの仕方に おける, 発達研究と臨床との相違があることも, 両領域 の研究者が明確に意識化せねばならない問題である。 